\title{
頸部迷走神経由来の巨大な神経鞘腫の一例
}

\author{
林 泰広 1$) \cdot$ 松井 和夫1) - 石田 直人 ${ }^{1)}$ \\ 鈴木 郁子1) ・ 松浦由美子2) ・ 名倉三津佳 ${ }^{3)}$

\section{Huge Schwannoma of the Cervical Vagus Nerve ; A Case Report} \\ Yasuhiro Hayashi, Kazuo Matsui, Naohito Ishida and Ikuko Suzuki \\ (Seirei Hamamatsu General Hospital) \\ Yumiko Matsuura \\ (Hamamatsu University School of Medicine) \\ Mitsuyoshi Nagura \\ (Fujinomiya General Hospital)
}

\begin{abstract}
A 70-year-old male was referred to us because of a constant sensation of a foreign body in the throat. He had undergone a tonsillectomy in another hospital. CT scan and MRI showed a giant and somewhat homogeneous soft tissue mass with fixation to the right sternocleidomastoid muscle. The tumor was removed together with the vagus nerve, and the fresh specimen measured $150 \times 50 \times 30 \mathrm{~mm}$ and $80 \mathrm{~g}$. A diagnosis of schwannoma derived from the vagus nerve was made on the basis of anatomic location of this huge tumor and pathological study. His constant sensation in the throat had completely disappeared postoperatively and no symptom was observed except for the persistent hoarseness. Six months later following the tumor extirpation, the patient underwent vocal fold augmentation by intracordal injection of atelocollagen, and his phonatory function improved.
\end{abstract}

Key words: schwannoma, cervical vagus nerve, MRI, sensation of a foregin body in the throat

\section{はじめに}

頸部迷走神経由来の神経鞘腫は比較的稀な疾 患である. 通常その主訴の大多数は無痛性の頸 部腫瘤であり, 腫瘤の圧迫により核嗽等の迷走 神経刺激症状が生じることが特徵とされている. しかし，これらの特徴を有する典型例はむしろ 少なく, 実際には術前診断は困難なことが多い.
最近我々は, 頸部迷走神経由来の巨大な神経鞘 腫の一例を経験した。 その主訴はいわゆる咽喉 頭異常感であり, 当初診断に手間どったが, 画 像診断が非常に有用であった．興味ある症例で あるので報告する。

\section{症例}

1）聖隷浜松病院耳鼻咽喉科

2) 浜松医科大学耳鼻咽喉科学教室

3）富士宮市立病院耳鼻咽喉科 
主訴：のどの異物感.

既往歴 : 高血圧.

家族歴 : 特記すべきことなし.

現病歴: 平成 2 年 9 月, 咽頭痛と右頸部圧痛 を訴光，近医内科を受診した。内服治療により， 疼痛は消失したが，のどに何かが引っかかって いるよらな異物感が残ったため, 某耳鼻咽喉科 を紹介された。慢性扁桃炎の診断にて，平成 2 年11月に両側口蓋扁桃摘出術を施行された。乙 かし，異物感が改善しないため，平成 3 年 6 月 12日，精査を希望して当科を初診した。

初診時所見：中咽頭から下咽頭，喉頭にかけ て軽度の発赤が認められ, 慢性的な炎症の存在 が考光られた。頸部の触診にて, 右総頸動脈分 岐部付近に圧痛を認めたものの，明らかな腫瘤 性病変は触知し得なかった。 反回神経麻痺は認 めず，頸部の圧迫による咳嗽反射も認めなかっ た.

一般検査所見：血液生化学的検査, 尿検査に は異常を認めなかった．胸部単純X線，心電図 にも異常を認めなかった。

頸部 CT, MRI 所見 : 経過が長く, 愁訴も強 いことより頸部の CT 検査を施行したところ， 右胸鎖乳突筋背側に接するように，上限は顎下 部から下限は上縦隔に及ぶ，製胞状で内部が不 均一に造影される巨大な腫瘤性病変が認められ た（図 1 )。ささら MRI 検査により, 冠状断 に捈いて上下方向に紡錐形に伸びる腫瘍を認め た（図 2 ）。この腫瘍は， $\mathrm{T} 1$ 強調像にて筋肉と ほぼ同様の比較的低輝度な信号, T2 強調像に て高信号を有する腫瘍と判明した。腫瘍による 内頸静脈と総頸動脈の解離が認められた。画像 診断上は，神経鞘腫が考えられた。

以上の所見により，改めて頸部の触診を丹念 に行うと, 右胸鎖乳突筋裏面に沿って弾性やや 硬の腫瘍が触知された．腫瘍は可動性に乏しく， 軽度の圧痛を認めた．触診のみでは腫瘍の全貌 を把握することは困難であると考兄られた，腫 瘍が巨大であり，さらに増大した場合には治療 が困難になると判断して，平成 3 年 9 月 27 日入
院の上，全身麻酔下に摘出術を施行した。

手術所見：全身麻酔下に右頸部に $\mathrm{T}$ 字型の皮 切を括き，胸鎖乳突筋を露出したのちこれを後 万へ圧排すると, 内頸静脈, 総頸動脈に接して

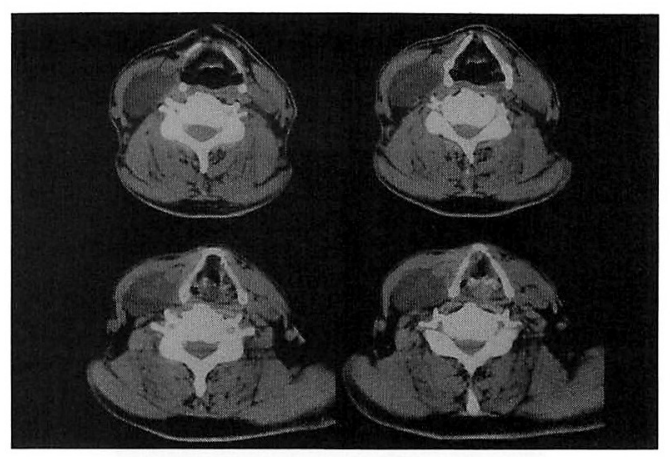

図 1 頸部 CT 所見

右胸鎖乳突筋背側に接して, 襄胞状で内部が不均 一飞造影される巨大な腫瘤性病変を認める。腫瘍 飞より右総頸動脈之内頸静脈は解離している.
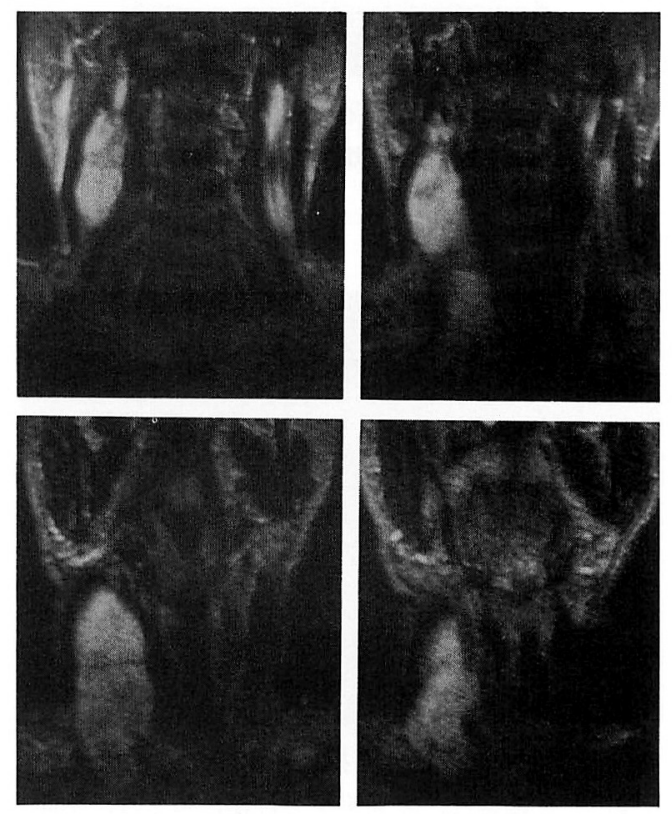

図 2 頸部 MRI 所見

$\mathrm{T} 2$ 強調像, 冠状断に括いて右胸鎖乳突筋背側に 接するように, 上限は罘下部から下限は上縦隔に 及ぶ，紡鍾形に伸びる腫瘍を認める。 
被膜に包まれた乳白色，弾性やや軟の腫瘍を認 めた，腫瘍は胸鎖乳突筋の裏面にほぼ全長にわ たり，軽度癒着していた（図 3 ）。周囲組織と の剥離は比較的容易だった。術中所見より腫瘍 は明らかに迷走神経由来であることが確認され た．迷走神経の走行を追い，健常部を上下に露 出したうえで，これを結紮切断し，腫瘍を摘出

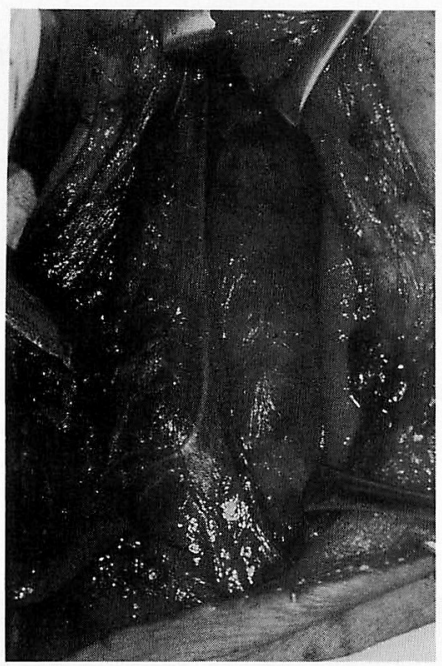

図 3 術中時所見

腫瘍は胸鎖乳突筋の裏面にほぼ全長にわたり， 軽度癒着していた。

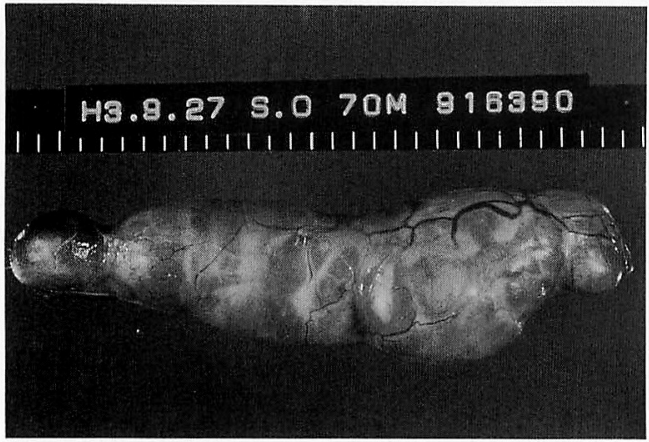

図 4 摘出標本

摘出した腫瘍は，表面平滑で被膜に包まれ，割面 は隔壁を有する慗胞状の部分と充実性の部分が混 在していた.大きさは, $150 \times 50 \times 35 \mathrm{~mm}$, 重量 $80 \mathrm{~g}$ に及んだ。
した.この際心電図, 血圧等にとくに異常は認 めなかった，摘出した腫瘍は，被膜に包まれ， 割面は隔壁を有する囊胞状の部分と充実性の部 分が混在していた．大きさは， $150 \times 50 \times 35$ $\mathrm{mm}$ ，重量 $80 \mathrm{~g}$ に及んだ（図 4 ）.

組織学的所見 : 病理組織像は Antoni A 型と Antoni B 型が混在する典型的な神経鞘腫だっ た（図 5 ）。悪性所見は認められなかった.

術後所見: 手術直後より右反回神経麻㾝を認 めた．右声帯は副正中に固定し，嗄声が生じた. また術後 2 日間, 軽度の誤曣が認められたが改 善した。術後経過は順調で，主訴ののどの異物 感は全く消失した。嗄声に対して平成 4 年 3 月 13日声帯内にアテロコラーゲンの注入術を行い， 現在経過は良好である。

\section{考察}

神経鞘腫は神経線維の最小単位である，軸索 を取り囲む Schwann 細胞から発生するとされ ている、したがって Schwann 細胞の存在する 場所であればどの部位においても発症し得る訳 であるが，比較的頸部に多く認められる11. 頸 部神経鞘腫のうち, 頸部迷走神経由来の神経鞘 腫は最も多いものとされる2). 本邦に打ける頸 部迷走神経鞘腫については, 多くの詳細な報告
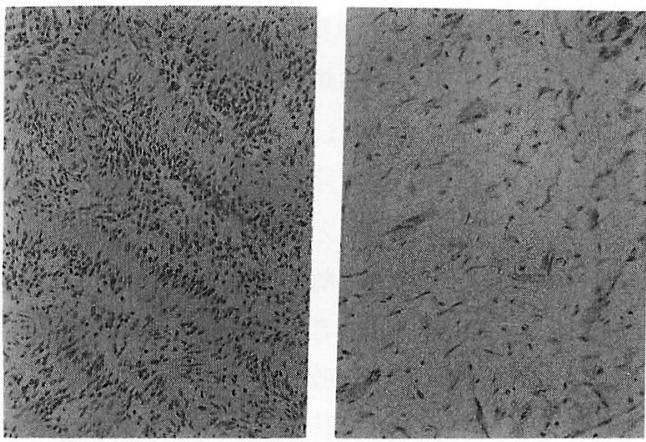

図 5 病理組織学的所見

病理組織像は図の左に示す様な，いわゆる観兵式 配列 (pallisade arrangement) を呈する Antoni A 型と, 右に示す様な, 細胞が不規則な網状に吻合 して粘液腫様の外観を呈する Antoni B型が混在 する典型的な神経䩗腫だった。 
がある2 〜5)。これらの報告の集計によると，頸 部迷走神経神経鞘腫の臨床的特徵はおよそ以下 のようにまとめられる。

(1)30歳代から50歳代に多く，男女差は余りな い. (2)罹患側は右側，上頸部がやや多い。(3)主 訴は大多数が頸部腫瘤である. (4)腫瘤の発育は 比較的緩除である. (5)触診上, 表面平滑, 境界 明膫, 無痛性で, 左右前後に可動性は認められ るが上下には制限されることが多い，(6)圧迫に より咳嗽反射や嗄声の出現をみることがある.

しかし，これらの症状をすべて満たす典型的 な症例は少ないよらである。したがって，上記 の症状を認めた場合にはとりあえず迷走神経由 来の神経鞘腫の可能性を疑って診断を進めるべ きである.

今回の我々の症例においては，(1)年龄は70歳, 男性. (2)罹患側は右側. (3)主訴は咽喉頭異常感. (4)腫瘤に関しては自覚症状なし. (5)触診上, 可 動性に乏しく，圧痛を認める腫瘤を触知する。

(6)圧迫による咳嗽反応や嗄声の出現なし. 以上, 上記の臨床的特徵があまり認められない非典型 例だった．慢性扁桃炎の存在があったことも診 断を困難にした。咽喉頭異常感のみを主訴とし た頸部迷走神経症例の報告は非常に稀である。

今回我々の症例で診断の決め手になったのは 画像診断であったが，本疾患の画像診断上の特 徵としては，CT にて不均一に造影される内部 構造が特徵的とされる. Antoni A 型と Antoni $\mathrm{B}$ 型の混在や, 囊胞変性などの病理組織像に由 来するものと考えられている6). 総頸動脈と内 頸静脈および内頸動脈と内頸静脈との間に腫瘤 が存在していることに注目し，動静脈解離現象 を重視する報告もある4)．MRI では T1 強調像 にて比較的低輝度な信号， T2 強調像にて高信 号を有する辺縁明瞭な像が得られることが特徵 的である。

外科的な摘出が唯一の治療法である. 迷走神 経を切断して腫瘍を全摘出するか，被膜下摘出 により迷走神経の温存を計るかについては問題 がある．理論的には神経鞘腫は腫瘍の内部に神
経束を巻き込まないので被膜下の完全摘出は可 能であるはずだが，実際には困難であろうと思 われる．とくに腫瘍が大きい場合には悪性転化 の懸念もあるので全摘が望ましいと考える. 術 後の合併症として最後まで問題になるのは，一 側の迷走神経切断による反回神経麻㽻のみとさ れている。耳鼻咽喉科医であれば音声改善術は 可能であり, 自覚的, 他覚的に嗄声の改善が得 られない場合には積極的にとりくむべきである と考える. 今回の症例については腫瘍摘出後, 半年経過観察の後, 声帯内にアテロコラーゲン 注入を行い経過良好である。

最後に, 今回の症例の場合, その主訴がいわ ゆる咽喉頭異常感であり, また慢性扁桃炎, 慢 性咽喉頭炎のあったことが，診断を遅らせる結 果となった. 腫瘍摘出後, 咽喉頭異常感が消失 したことより，神経鞘腫が異常感の原因であっ たと考えられた，腫瘍が巨大であったことによ る単純な圧迫症状だったと考えられるが，経過 が長く，また碩固な訴えが続く場合にはいたず らに先入観に捕われることなく，精査を行ら必 要があると考光られた。

\section{まとめ}

1 ）咽喉頭異常感を主訴にした，巨大な頸部 迷走神経由来の神経鞘腫の一例を報告した.

2) CT および MRI が診断に有用であった.

3 ) 術後の嗄声に対して声帯内にアテロコ ラーゲン注入を行い経過良好である。

本論文の要旨は第 2 回日本気管食道科学会認定医 大会に扣いて発表した。

\section{文献}

1) Batsakis JG : Tumors of the Head and Neck 2 nd ed. pp 313 315, William \& Wilkins, Baltimore, London, 1979.

2）平出文久, 西澤伸志: 神経系頸部腫瘤. 耳鼻咽 喉科・頭頸部外科 MOOK (斎藤 等編). 112 ～121頁, 金原出版, 東京, 1986 .

3）田中憲雄, 宮村健一郎, 猪川 勉, 他: 頸部迷 走神経より生じた神経䩪腫. 耳鼻臨床 $75: 63$ $\sim 72,1982$. 
4）古川政樹, 山下耕太郎，金子まどか，他：頸部 迷走神経より発生した神経䩗腫の 3 例. 日耳鼻 $91: 1256 \sim 1266,1988$.

5）小川佳伸, 久保雅世, 山中敏彰, 他 : 頸部迷走 神経原発の神経鞘腫の一例. 耳鼻臨床 補 37 ： 310 321, 1990.

6) Silver AJ, Mawad ME, Hilal SK, et al : Com- puted tomography of the carotid space and related cervical spaces part-2; neurogenic tumor. Radiology $150: 729 \sim 735,1984$.

(別刷請求先 : 林 泰広 厂430 静岡県浜松市住吉2-12-12 聖隷浜松病院耳鼻咽喉科 